\title{
Polymorphism of genes of methylenetetrahydrofolate reductase, glutathione $S$-transferases $P 1$ and M1, cytochrome P450 1A1 and glutathione S-transferase activity in human placenta
}

\author{
O.P. Martsenyuk ${ }^{1,2}$, L.Y. Sazonova', C. Mislanova ${ }^{3}$, M.Yu. Obolenskaya ${ }^{1}$ \\ ${ }^{1}$ The Institute of Molecular Biology and Genetics, NAS of Ukraine \\ 150, Academician Zabolotny Str., Kyiv, 03143, Ukraine \\ ${ }^{2}$ National Taras Shevchenko University of Kyiv, \\ 64, Volodymyrska Str., Kyiv, 01033, Ukraine. \\ ${ }^{3}$ The Institute of Preventive and Clinical Medicine \\ 14, Limbova, 83301 Bratislava, Slovak Republic \\ o.p.martsenyuk@imbg.org.ua
}

\begin{abstract}
For the first time the prevalence of C677T methylenetetrahydrofolate reductase (MTHFR) genotypes was detected in a cohort of Ukrainian population. We have analyzed the association of polymorphism of MTHFR alone and in its combination with polymorphic genes coding for glutathione S-transferase P1, glutathione S-transferase M1, and cytochrome P450 1 A1 with cytosolic glutathione S-transferase activity in human placenta samples. The substitution of C6774T677 in at least one allele of MTHFR gene is accompanied by the tendency of GST activity to increase. The tendency remains irrespective of allelic variants of other three genes in specified combinations. The possible relation between the MTHFR allelic variants and cytosolic glutathione S-transferase activity is discussed.
\end{abstract}

Keywords: single nucleotide polymorphism, methylenetetrahydrofolate reductase, glutathione S-transferase PI and M1, glutathione S-transferase activity, human placenta.

Introduction. The condition of environment and demographic situation in Ukraine are two issues which acquired especial importance in the years after Chernobyl disaster. The essence of the problem lies in the fact that in most of the cases clinicians observe complicated pregnancies with the birth of not absolutely healthy child. The cases of intrauterine growth retardation, recurrent pregnancy loss, still birth, miscarriage, etc., present some influence on the demographic situation in Ukraine. Taking the

(C)O.P. MARTSENYUK, L.Y. SAZONOVA, C. MISLANOVA, M.YU. OBOLENSKAYA, 2006 aforementioned into account, the studies on the factors influencing the pregnancy complications are important tasks for the science and medicine in this country.

Polymorphism of the key enzyme of the cycle of activated methyl group - methylenetetrahydrofolate reductase (MTHFR) (EC 1.7.99.5), is one of the genetic causes of complicated pregnancy and congenital abnormalities. MTHFR catalyzes irreversible restoration of $\mathrm{N}^{5}, \mathrm{~N}^{10}$-methylenetetrahydrofolate to $\mathrm{N}^{5}$ - methyltetrahydrofolate $\left(\mathrm{N}^{5}\right.$-MeTHF) [1]. $\mathrm{N}^{5}, \mathrm{~N}^{10}$-methylenetetrahydrofolate and its oxidated derivatives $\mathrm{N}^{10}$-formyland $\mathrm{N}^{5}, \mathrm{~N}^{10}$-methenyltetrahydrofolate donate one-carbon 
units for thymidylate and purine syntheses. $\mathrm{N}^{5}$-MeTHF itself is a donor of methyl group for remethylation of homocysteine in the cycle of activated methyl group and thus is an indispensable substance for numerous methylation reactions with S-adenosylmethionine (SAM) and methyltransferases [2].

The most studied single nucleotide polymorphism of MTHFR gene is a substitution of 677 cytosine to thymine $(677 \mathrm{C} \rightarrow \mathrm{T})$. This point mutation causes the conversion of alanine 222 to valine and is associated with thermolability and decreased catalytic activity of enzyme [3]. The functioning of this isoform is associated with limited methylation, particularly, DNA methylation and, therefore, may change gene expression. One of the main consequences of decreased methylation of genes promoters, especially CpG-enriched ones, is the activation of corresponding genes. DNA methylation is an important regulator of cell differentiation, especially during its rapid changes at the first stages of embryogenesis. Its slight disorder may have negative effect on fetus.

Combination of C677T or T677T allelic variants of MTHFR with deficiency of folic acid consumption increases the risk of pregnancy complications and fetal malformations [4]. To prevent this effect the women are prescribed a double daily dose of folic acid before conception and at least during the first 12 weeks of pregnancy though unfortunately without preliminary maternal and fetal genotyping.

The aim of current work was to find out the frequency of allelic variants of MTHFR gene in Ukrainian population and their influence on placenta phenotype. Glutathione S-transferase (GST) activity of placenta cytosol was selected as a surrogate marker of gene expression. The GSTP1 gene encodes the major protein of human placenta and GSTP1 catalytic activity comprises about $85 \%$ of total GST activity in the tissue. The promoter of GSTP1 gene is highly CpG-enriched and its methylation defines the intensity of transcription.

The analysis of cytosolic GST-activity in the samples with different allelic variants of MTHFR gene and genes, coding for GSTP1, M1 and cytochrome P450 1A1, revealed polymorphism of MTHFR gene to have substantial effect on catalytic activity of the enzyme.
Materials and Methods. Samples of mature placenta (38-42 weeks of pregnancy) were obtained immediately after delivery or cesarean operation in maternity departments of Kyiv, Zaporizhzhya (Ukraine), Gomel (southern Belarus) as well as in the department of obstetrical pathology of the Institute of Pediatrics, Obstetrics, and Gynecology (Kyiv). The pollution in the ambient air, the radioactive contamination in the indicated regions, clinical characteristics as well as the technology of obtaining samples, their treatment and keeping were described in $[5,6]$. Placenta samples were obtained from persons who introduced themselves as non-smokers, not alcohol dependent, were not drug addicts and did not have professional contacts with xenobiotics.

Samples collection was performed according to established ethical norms concerning the work with human tissues.

DNA was extracted from placenta samples in approximately $50 \mathrm{mg}$ according to the method described in [7].

Genotyping of methylenetetrahydrofolate reductase was performed using polymerase chain reaction (PCR) with subsequent restriction analysis of amplification product. To control restriction reaction, a fragment of fibrinogen gene A $\alpha$ was amplified together with the fragment of MTHFR gene. Fragments of fibrinogen gene $A \alpha$ and 677T alleles of MTHFR gene have restriction sites for HinfI restrictase. The sequence of primers for amplification of indicated fragments was taken from [8] and presented below:

For MTHFR fragment

A: 5'-TGA AGG AGA AGG TGT CTG CGG GA-3'

B: 5'-AGG ACG GTG CGG TGA GAG TG-3'

For Fibrinogen Аб fragment

C: 5' -CTC CCT TCA CTT TCA GAA CTA CA-3'

D: 5'-GAC CTC TCA GTT TTC ACC TTT A-3'

Reaction mixture for PCR (total volume $50 \mathrm{mkl}$ ) contained $1 \mathrm{mkg}$ DNA, four nucleoside triphosphates, 0.2 mM each ("MBI Fermentas", Lithuania), 10 pmol of each primer ("Sintol" Ltd, Russia) and 2.5 unit of Taq polymerase in the buffer $10 \mathrm{mM}$ tris- $\mathrm{HCl}, \mathrm{pH} 8.8,50 \mathrm{mM}$ $\mathrm{KCl}, 1.5 \mathrm{mM} \mathrm{MgCl}_{2}$. Amplification reaction consisted of preliminary denaturation $\left(94^{\circ} \mathrm{C}, 4 \mathrm{~min}\right), 30$ amplification 
cycles (denaturation $-94^{\circ} \mathrm{C}, 30 \mathrm{sec}$, primer annealing $58.5^{\circ} \mathrm{C}, 30 \mathrm{sec}$, polymerization $-72^{\circ} \mathrm{C}, 50 \mathrm{sec}$ ) and completing polymerization $\left(72^{\circ} \mathrm{C}, 7 \mathrm{~min}\right)$.

Intermediary control electrophoresis of PCR products was performed in $2 \%$ agarose gel in the $1 \mathrm{x}$ TBE buffer.

Restriction mix (total volume $25 \mathrm{mkl}$ ) contained 14 Ml of PCR reaction mix, 10 units of restrictase Hinfl and $0.1 \mathrm{mg} / \mathrm{ml} \mathrm{BSA}$ in $10 \mathrm{mM}$ tris-HCl, $\mathrm{pH} 8.5,10 \mathrm{mM}$ $\mathrm{MgCl}_{2}, 100 \mathrm{mM} \mathrm{KCl}$ buffer. The reaction lasted 2-4 hours at $37^{\circ} \mathrm{C}$. Electrophoresis of restriction products was performed in 3\% TopVision agarose ("MBI Fermentas") and $1 \mathrm{x}$ TBE buffer. The results of electrophoresis were visualized using Ultroscan.

The data on cytosolic GST-activity and CYP1A1, GSTP1 and GSTM1 genotyping in investigated placenta samples were taken from our publication [5]. Cytosolic GST-activity was determined in the reaction with chlorodinitrobenzene (CDNB) [9] and genotyping of enzymes - by PCR with subsequent restriction analysis.

The GST-activity is presented as medians with 95-\% confidence interval (CI). The statistical significance of the difference between GST-activity classified according to the genotypes of investigated enzymes was estimated by Mann-Whitney criterion using StatSoft, Statistica release 6.0.

Results and Discussion. To detect allelic variant of MTHFR gene, we used amplification of corresponding gene fragment together with the fragment of fibrinogen gene with subsequent restriction analysis of amplification products (Fig. 1). Selected fragment of fibrinogen gene has two restriction sites for Hinfl restrictase and is cut by it into three fragments, 56, 136 and 360 b.p. The $677 \mathrm{~T}$ allelic variant of MTHFR gene has one restriction site for Hinfl restrictase and is cut by it into two fragments, 175 and $23 \mathrm{bp}$. This site is absent in the allelic variant of MTHFR gene with $677 \mathrm{C}$ and PCR product after restriction is revealed as a full-size $198 \mathrm{bp}$ fragment. Homo- and heterozygous carriage is revealed according to the presence of corresponding fragments.

The prevalence of C677T allelic variants of MTHFR gene in the investigated cohort of Ukrainian population does not differ significantly from that in European population [10]. According to our data it is equal to $45.8 \%$ (44/96) for C677C, $43.8 \%$ (42/96) for

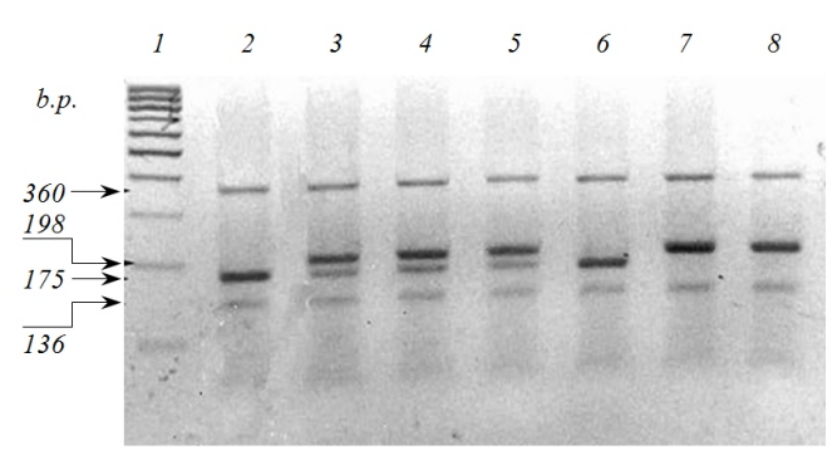

Fig.1 Electrophoregram of restriction products of amplified fragments of MTHFR and fibrinogen Aб genes: 1 - marker of molecular weight; 2, 6 carriage of T677T alleles of MTHFR gene; 3-5 - carriage of C677T alleles of MTHFR gene; 7, 8 - carriage of C677C alleles of MTHFR gene

C677T and 10.4\% (10/96) for T677T genotypes of MTHFR gene (Fig. 2). There was not observed any difference in allelic prevalence between the samples from different regions of Ukraine and southern Belarus.

Previously we have evaluated cytosolic GST-activity and the prevalence of allelic variants of genes encoding GSTP1, GSTM1, and CYP1A1 in placental samples that were used in this study. GST-activity is associated with the genotype of above-enumerated enzymes. Its down-regulation is more pronounced in the exposed pregnancies from the regions with chemically polluted or radioactively contaminated environment than from those justified as 'clean' ones. The decrease of cytosolic GST activity was accompanied by complications in the course of pregnancy and delivery as well as by deterioration in the health of newborn [5, 6, 12-14].

We have confirmed that decrease of GST activity is at least partly defined by down-regulated gene expression [14]. One of the potential reason of GSTP1 down-regulated expression is methylation of its CpG-enriched promoter that induces the gene silencing. The methylation of DNA depends on the availability of methyl-group that is donated into methyl cycle by N5-MeTHF. The latter is restored from N5, N10-methylenetetrahydrofolate by MTHFR, a key enzyme of folate-mediated one carbon-unit metabolism. That is why we have compared cytosolic GST-activity as a surrogate marker of GSTP1 gene expression with the allelic variants of MTHFR gene. 

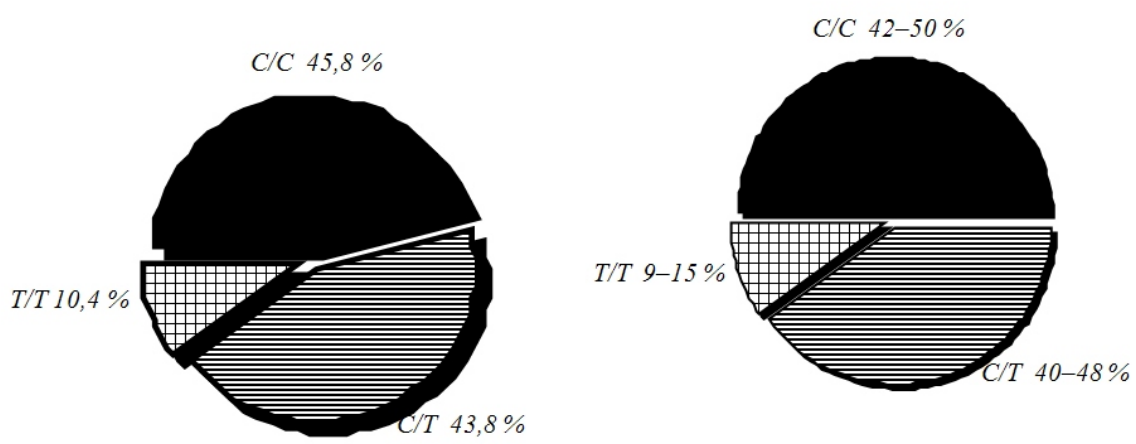

Fig.2 Frequency of C677T allelic variants of MTHFR gene in the investigated cohort of Ukrainian population (a) and in Europe (b) $[1,11]$

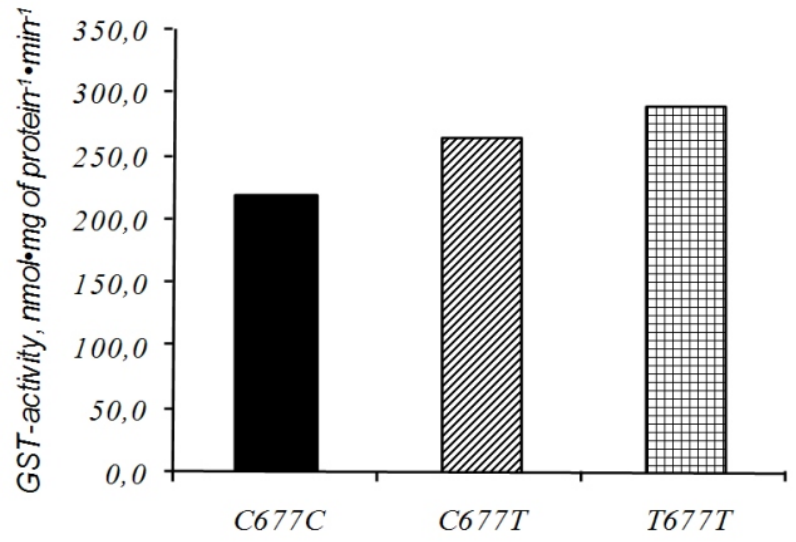

Fig.3 Cytosolic glutathione S-transferase activity in human placenta samples with different allelic variants of MTHFR gene: 1 - C677C; 2 C677T; 3 - T677T

GST-activity was found to be higher at $\mathrm{C} \rightarrow \mathrm{T}$ substitution in both alleles of MTHFR gene i.e. at T677T genotype than that at C677C genotype:

$290.8 \mathrm{nmol} \mathrm{mg} \mathrm{protein}{ }^{-1} \min ^{-1}$ (95\% CI: 208.69 - $350.73 \mathrm{nmol} \mathrm{mg}$ protein-1 min-1) versus $220.1 \mathrm{nmol} \mathrm{mg}$ protein ${ }^{-1} \mathrm{~min}^{-1}$ (95\% CI: 201.63 - $279.52 \mathrm{nmol}$ mg protein-1 min-1), $\mathrm{p}=0.17$ according to Mann-Whitney test.

At $\mathrm{C} \rightarrow \mathrm{T}$ substitution in one allele of MTHFR gene only, GST-activity has intermediate value $-265.5 \mathrm{nmol}$ $\mathrm{mg}_{\text {protein }}{ }^{-1} \min ^{-1}$ (95\% CI: $227.75-318.88 \mathrm{nmol} \mathrm{mg}$ protein $\left.^{-1} \min ^{-1}\right)$ - between activity in samples with dominant (C677C) and recessive (T677T) homozygotes of MTHFR, Mann-Whitney test is $\mathrm{p}=0.3$ and $p=0.17$ respectively (Fig. 3 ). Therefore, enzymatic activity of GST reveals the tendency to increase depending on the presence of MTHFR gene mutation in one or two alleles. The absence of statistically significant difference $\mathrm{p} \leq 0.05$ between GST-activity in the samples, carrying different allelic variants of MTHFR gene may be connected with insufficient number of samples.

It is well known that GST activity depends on numerous factors, including genetic and external ones. We have previously confirmed the association of placental cytosolic GST-activity with the allelic variants of genes, encoding the main detoxication enzymes in placenta-GST P1 and M1, cytochrome P450 1A1 [15, 16] - as well as with adverse agents in polluted environment [5]. The task of this research was to find out which factors are more or less influential in their combination. Therefore, we classified placenta samples according to combination of genotypes of four enzymes, namely, MTHFR, GSTP1, GSTM1, CYP1A1. Four polymorphic genes, each of which may be in three variants of specified single nucleotide (two homozygous and one heterozygous) may theoretically form $3^{4}=81$ combinations. 17 combinations of allelic variants of abovementioned genes were revealed in investigated samples. Each combination contained nearly equal number of placenta samples, collected from different regions of Ukraine, therefore, the influence of environment was not considered. Twelve combinations, occurring with over 2\% frequency, were numbered in ascending order of median value of cytosolic GST-activity and presented in the Table. Using Mann-Whitney criterion, GST-activity was analyzed in combinations which differed only in allelic variants of one among four genes, three others being the same. The abovementioned association between allelic variants of MTHFR gene and GST-activity is preserved at intergroup comparison, regardless insignificant number of samples in each group. 
Table

Combination of allelic variants of MTHFR, GSTP1, GSTM1 and CYT1A1 genes and cytosolic glutathione S-transferase activity in human placenta samples

\begin{tabular}{|c|c|c|c|c|c|c|}
\hline \multirow[b]{2}{*}{ Combination \# } & \multicolumn{4}{|c|}{ Combinations of allelic variants } & \multirow{2}{*}{$\begin{array}{l}\text { Cytosolic GST-activity nmol mg } \\
\text { protein-1 } \min -1(95 \% \mathrm{CI})\end{array}$} & \multirow[b]{2}{*}{$\begin{array}{l}\text { Carriage } \\
\text { frequency }\end{array}$} \\
\hline & $\begin{array}{l}\text { MTHFR } \\
\text { C677T }\end{array}$ & $\begin{array}{l}\text { GSTP1 } \\
\text { A1403G }\end{array}$ & GSTM1 +/- & $\begin{array}{l}\text { CYP1A1 } \\
\text { A2455G }\end{array}$ & & \\
\hline 1 & $\mathrm{C} / \mathrm{C}$ & $\mathrm{A} / \mathrm{G}$ & + & $\mathrm{A} / \mathrm{A}$ & $156.40(24.66-322.59)$ & $4 / 57$ \\
\hline 2 & $\mathrm{C} / \mathrm{C}$ & $\mathrm{A} / \mathrm{G}$ & - & $\mathrm{A} / \mathrm{A}$ & $168.55(132.91-228.28)$ & $10 / 57$ \\
\hline 3 & $\mathrm{C} / \mathrm{C}$ & $\mathrm{A} / \mathrm{A}$ & + & $\mathrm{A} / \mathrm{A}$ & $173.79(65.89-324.35)$ & $4 / 57$ \\
\hline 4 & $\mathrm{C} / \mathrm{T}$ & $\mathrm{G} / \mathrm{G}$ & - & $\mathrm{A} / \mathrm{A}$ & $180.39(120.32-228.08)$ & $7 / 57$ \\
\hline 5 & $\mathrm{C} / \mathrm{T}$ & $\mathrm{A} / \mathrm{G}$ & - & $\mathrm{A} / \mathrm{A}$ & $225.80(149.13-283.17)$ & $6 / 57$ \\
\hline 6 & $\mathrm{C} / \mathrm{C}$ & $\mathrm{A} / \mathrm{A}$ & - & $\mathrm{A} / \mathrm{A}$ & $258.83(126.09-323.71)$ & $6 / 57$ \\
\hline 7 & $\mathrm{C} / \mathrm{T}$ & $\mathrm{A} / \mathrm{G}$ & + & $\mathrm{A} / \mathrm{A}$ & $234.12(112.54-339.78)$ & $4 / 57$ \\
\hline 8 & $\mathrm{C} / \mathrm{T}$ & $\mathrm{A} / \mathrm{A}$ & + & $\mathrm{A} / \mathrm{A}$ & $289.36(190.77-332.32)$ & $6 / 57$ \\
\hline 9 & $\mathrm{~T} / \mathrm{T}$ & $\mathrm{A} / \mathrm{G}$ & + & $\mathrm{A} / \mathrm{A}$ & $290.84(247.74-318.94)$ & $4 / 57$ \\
\hline 10 & $\mathrm{~T} / \mathrm{T}$ & $\mathrm{A} / \mathrm{A}$ & + & $\mathrm{A} / \mathrm{A}$ & 303.80 & $2 / 57$ \\
\hline 11 & $\mathrm{C} / \mathrm{T}$ & $\mathrm{A} / \mathrm{A}$ & + & $\mathrm{A} / \mathrm{G}$ & 329.87 & $2 / 57$ \\
\hline 12 & $\mathrm{C} / \mathrm{T}$ & $\mathrm{A} / \mathrm{A}$ & - & $\mathrm{A} / \mathrm{G}$ & 384.20 & $2 / 57$ \\
\hline
\end{tabular}

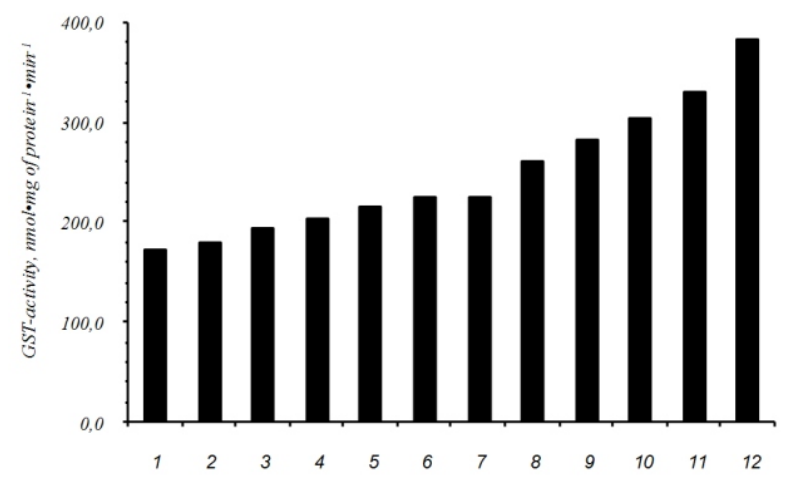

Fig.4 Cytosolic glutathione S-transferase activity in the samples with different combination of allelic variants of MTHFR, GSTP1, GSTM1 and CYP1A1 genes The numeration of combinations of allelic variants of genes is presented in accordance with the Table

The substitution of one $677 \mathrm{C}$ allele for $677 \mathrm{~T}$ allele (let us compare combinations 5 and 2 and combinations 8 and 3) and substitution of both $\mathrm{C}$ alleles for $\mathrm{T}$ (combinations 9 and 1 and combinations 10 and 3) are associated with the increase in median values of GST-activity (Table, Fig. 4). The difference between GST-activity of samples, in which MTHFR gene is in different homozygous conditions (compare combinations 9 and 1 and combinations 10 and 3), is higher than between GST-activity in samples with hetero- and homozygous gene (combinations 5 and 1 and combinations 8 and 3). Similar analysis, performed for GSTP1 and GSTM1 genes, confirmed present views on the interconnection between allelic variants of these genes and GST-activity, namely, $A \rightarrow G$ substitution in nucleotide 1403 of GSTP1 gene (combinations 2 and 6) and deletion in GSTM1 gene (combinations 5 and 7) are associated with the GST-activity decrease $[14,15]$. The difference between GST-activity at different genotypes of GST genes is surprisingly less manifested that at different genotypes of MTHFR gene. The increase in GST-activity is observed also in the samples with combination 11 comparing to 8, which differ in allelic variants of CYP1A1. Substitution 462Ile $\rightarrow$ Val in the enzyme molecule is reflected in combination 11.

Thus, the analysis of cytosolic GST-activity in human placental samples depending on combination of allelic variants of four polymorphic genes, GSTP1, GSTM1, CYP1A1 and MTHFR, has revealed the increase in cytosolic GST-activity due to mutation in at least one allele in MTHFR gene independently of 
allelic variants of other three polymorphic genes. The values of cytosolic GST-activity in the samples with C677C, C677T, and T677T genotypes of MTHFR gene are arranged in ascending order.

Conclusions. The prevalence of C677T allelic variants of MTHFR gene in the investigated cohort of Ukrainian population does not differ significantly from that in European population. It is equal to $45.8 \%$ (44/96) for C677C, 43.8\% (42/96) for C677T and $10.4 \%$ (10/96) for T677T genotypes of MTHFR gene.

The cytosolic GST catalytic activity in human placenta reveals the tendency to increase with $677 \mathrm{C} \rightarrow \mathrm{T}$ substitution in one or two alleles in MTHFR gene independently of allelic combination of the genes GSTPP1, GSTM1 and CYP1A1.

\section{Acknowledgements}

The work was carried out with the financial support of the grant from the President of Ukraine for talented young people 2006-2007 (O.M.) and joint Ukrainian-Slovakian grant №M/152-2006 (O.M., Ch.M., M.O).

The authors express their sincere gratitude to A. M. Slonchak for his help in developing the method of MTHFR genotyping.

\section{О. П. Мариенюк, Л. Я. Сазонова, Ч. Мишланова, М. Ю. Оболенськая}

Полиморфизм генов метилентетрагидрофолатредуктазы, глутатионтрансфераз Р1 и М1, цитохрома P450 1А1 и глутатионтрансферазная активность в плаценте человека

\section{Резюме}

Впервые исследована частота распространения С677Т аллельных вариантов гена метилентетрагидрофолатредуктазы (МТГФР) в ограниченной популяции жителей Украины и проанализирована глутатионтрансферазная активность цитозоля в образиах плащенты с разными аллельными вариантами гена МТГФР в комбинации с полиморфныли генами глутатионтрансфераз $P 1$, М1 и ичитохрома P4501A1. При замене С677®Т677 хотя бы в одном из аллелей гена МТГФР обнаружена тенденция к повышению глутатионтрансферазной активности, сохраняющаяся независимо от того, в комбинации с какими аллельными вариантами других исследуемых генов находится ген МТГФР. Обсуждается возможная связь между аллельными вариантами гена МТГФР и глутатионтрансферазной активностью.

Ключевые слова: полиморфизм генов, метилентетрагидрофолатредуктаза, глутатионтрансферазы P1 и M1, плачента человека, глутатионтрансферазная активность.

\section{REFERENCES:}

1. Matthews $R$. G. Methylenetetrahydrofolate reductase: a common human polymorphism and its biochemical implications // Chem. Rec.-2002.-2.-P. 4-12.

2.Van der Put N. M., Gabreels F., Stevens E. M., Smeitink J. A., Trijbels F. J., Eskes T. K., van den Heuvel L. P., Blom H. J. A second common mutation in the methylenetetrahydrofolate reductase gene: an additional risk factor for neural-tube defects // Amer. J. Hum. Genet.-1998.-62.-P. 1044-1051.

3.Heijmans B. T., Boer J. M., Suchiman H. E., Cornelisse C. I., Westendorp R. G., Kromhout D., Feskens E. I., Slagboom P. E. A common variant of the methylenetetrahydrofolate reductase gene (1p36) is associated with an increased risk of cancer // Cancer Res.-2003.-63.-P. 1249-1253.

4.Mills J. L., McPartlin J. M., Kirke P. N., Lee Y. J., Conley M. R., Weir D. G., Scott J. M. Homocysteine metabolism in pregnancies complicated by neural-tube defects // Lancet.-1995.-345.-P. $149-151$.

5.Теплюк Н. М., Лебедева Л. М., Коломиеи Л. И., Буткевич Д. М., Хоронжи М. Р., Пуарье М. С., Оболенская М. Ю. Фено- и генотипирование дезинтоксикационной системы плаценты в экологически неблагоприятных районах Украины // Укр. біохім. журн.-2001.-73, № 3.-С. 126-134.

6.Оболенська М. Ю., Чайковська Т. Л., Лебедєва Л. М., Теплюк Н. М., Коломієиь Л. І., Іванська Н. В., Віденко Л. В., Некрич В. В., Бурлак Г. Ф. Дезінтоксикаційна функція плаценти у породіль 3 екологічно несприятливих районів України // Укр. біохім. журн.-1997.-70, № 2.-С. 89-97.

7.Miller S. A., Dykes D. D., Polesky H. F. A simple salting out procedure for extracting DNA from human nucleated cells // Nucl. Acids Res.-1988.-16.-P. 1.

8.Van Amerongen G., Mathonnet F., Boucly C., Mathieu B., Vinatier I., Peltier I. J., Catherine N., Collet C., de Mazancourt P. An improved method for the detection of the thermolabile variant of methylenetetrahydrofolate reductase // Clin. Chem.-1998.-44.-P. 1045-1047.

9.Habig W. H., Pabst M. J., Jakoby W. B. Glutathione-S-transferase // J. Biol. Chem.-1974.-249.-P. 7130-7139.

10.McAndrew P. E., Brandt J. T., Pearl D. K., Prior T. W. The incidence of the gene for thermolabile methylene tetrahydrofolate reductase in African Americans // Thromb. Res._1996._83.—P. 195-198.

11.Gasparovic J., Raslova K., Basistova Z., Zacharova M., Wsdova L., Avdicova M., Blazicek P., Lietava I., Sivakova D. Effect of C677T methylenetetrahydrofolate reductase gene polymorphism on plasma homocysteine levels in ethnic groups // Physiol. Res.-2004.-53.-P. 215-218.

12.Теплюк Н. М., Лебедєва Л. М., Сазонова Л. Я., Самойленко А. А., Щербина М. С., Перепелюк М. М., Оболенська М. Ю. Детоксикаційна функція плаценти людини та їі особливості залежно від генотипів цитохрому P450 1А1, глутатіонтрансферази P1 та M1 // Наук. записки Києво-Могилян. акад.-2002.-20, № 2.-С. $445-447$.

13.Теплюк Н. М., Мельник А. Ф., Діві Р. Л., Пуарье М. С., Оболенська М. Ю. Глутатіонтрансферазна активність і ДНК-аддукти в плаценті людини в умовах несприятливого довкілля // Наук. записки Києво-Могилян. акад.-2003.-22, № 3.-С. 379-382.

14.Obolenskaya M., Teplyuk N., Prima V., Malko M., Bondarenko E., Didenko L., Vit V., Divi R., Poirier M., Pasanen M. Glutathionetransferase activity and PAH-DNA adducts in human placenta as a risk factor for new-born in radioactively contaminated regions // Int. J. Radiat. Med.-2004.-6.-P.154-166.

15.Crofts F., Cosma G. N., Currie D., Taioli E., Toniolo P., Garte S. J. A novel CYP1A gene polymorphism in African-Americans // Carcinogenesis.-1993.-14.-P. 1729-1731.

16.Zimniak P., Nanduri B., Pikula S., Bandorowicz-Pikula J., Singhal S. S., Srivastava S. K., Awasthi S., Awasthi Y. C. Naturally occuring human glutatione S-transferase GSTP1-1 isoforms with isoleucine and valine in position 104 differ in enzymic properties // Eur. J. Biochem.-1994.-224.-P.893-899.

Надійшла до редакці1 107.03 .06 